УДК $343.2 / .7$

DOI https://doi.org/10.32837/apdp.v0i85.1819

Н. В. Басалюк

\title{
СИСТЕМА ПОКАРАНЬ У ДОКТРИНІ КРИМІНАЛЬНОГО ПРАВА УКРАЇНИ
}

Постановка проблеми. Формування юридичного світогляду XXI ст. відбувається шляхом перегляду багатьох понять кримінального права. У зв'язку із необхідністю удосконалення системи українського законодавства, звернення до витоків теоретичної правової науки є необхідним. Кримінально-правова наука може розвиватися, опираючись на практичний досвід, відображений у роботах юристів. Дослідження вчень дореволюційних й радянських правників можуть допомогти визначити орієнтири розвитку сучасного кримінального права.

Аналіз останніх досліджень і публікацій. Вивченням загальних питань доктрини кримінального права займалися вітчизняні вчені, серед яких Ю. Баулін, П. Андрушко, В. Навроцький, М. Панов, Є. Стрельцов, П. Фріс, Є. Полянський, Ю. Коломієць, О. Костенко та інші та зарубіжні науковці, у числі яких, С. Бошно, О. Васильєв, В. Лоба та інші.

Метою статті є дослідження становлення і розвитку доктрини системи покарань у вітчизняній науці кримінального права.

Виклад основного матеріалу дослідження. Система покарань, як кримінально-правова конструкція пройшла у своєму розвитку певні періоди.

Перший етап характеризувався появою наукових підходів до дослідження не системи покарань, як правової категорії, а окремих видів покарань на конкретному історичному етапі; відбулося зародження і систематизація законодавства; закріплення видів покарань в актах царської доби привернуло увагу вчених до їх дослідження. Цей етап був дуже тривалим: від утворення Київської русі у IX ст. і до формування радянського кримінального права у 1917 р. Темпоральні межі другого етапу простягаються з 1917 р. до 1922 р., що завершився прийняттям першого кодифікованого акта - Кримінального кодексу УРСР. Законодавчий процес ідейної еволюції у поглядах на систему покарань розпочався девізом: «Ти винен в тому, що ти - буржуазія». Історико-політичні зміни призвели до повного перегляду поглядів на систему покарань, що знайшло своє відображення і у радянському законодавстві, і у тодішній доктрині. Третій етап тривав з 1922 р. до 1927 р. - абсолютна більшість робіт, присвячених вказаній темі будувалася крізь призму революційних цінностей. Четвертий етап простягнувся у межах з 1927 р. до 1960 р. На цьому етапі особливо розвинулося вчення соціологічної школи; радянські юристи підтримували застосування аналогії, підкорили систему покарань політичним інтересам, а верховенство закону остаточно замінили революційною правосвідомістю. П'ятий етап тривав з 1960 р. до 2001 р. і охарактеризувався відміною класового принципу, смертної кари (1999р.) й ряду інших покарань, що супроводжували радянське «будівництво» - часто у максимально вузькому значенні цього слова. Шостий етап розпочався у 2001 р. з моменту прийняття нового Кримінального ко- 
дексу й триває до теперішнього часу. Юридична думка і законодавча течія стали на шлях гуманізації. Він характеризується науковими пошуками окремих питань класифікації видів покарань, підстав, порядку та особливостей застосування основних та додаткових, строкових та безстрокових видів й виробленням стрункої системи покарань, її оптимальності з урахуванням багаторівневості явища.

У IX столітті Давньоруська держава упевнено заявила про своє існування - велика, культурна, могутня. Разом із новою державою відбулося формування руського права, основу якого складали звичаєві норми. Покарання були відомі історії задовго до часів Руської Правди, однак, попри відсутність поділу на галузі права, саме у ній відобразилася спроба їх систематизації.

«Руська правда» як цінна звістка подій давньоруської доби не піддавалася якимось доктринальним дослідженням у період свого існування. А окремі літописи - важливе джерело історії і культури - за вірним акцентом I.К. Чугаєвої: «пріоритетними темами для літописців були стихійні лиха... релігійні події, сімейна хроніка князів, а також військово-політичні кампанії володарів Русі всередині князівства...» [13, с. 7], але не права, хоча, в окремих документах можна знайти дещо й про покарання. Так, Галицько-Волинський літопис говорить про встановлення Мстиславом «ловче на берестян... щоби мені не дивитися на їх кров», тобто князь замінив цією податтю тілесну кару [4, с. 160]. I лише у XIX ст. з'явилося декілька змістовних досліджень, що були присвячені питанням давньоруського права, серед таких праці А. Рейца «Досвід історії Російських державних і цивільних законів» (1836), О.М. Попова «Руська правда у відношенні до кримінального права» (1841), М.В. Калачова «Попередні юридичні відомості для повного пояснення Руської Правди» (1846) та інші. У роботах вказаних авторів не йшлося про реформування кримінального права чи окремих його питань, вони, перш за усе - представники офіційної історіографії, у роботах яких спроба адекватно відобразити правові реалії Давньоруської держави.

Юридична наука лише починає складатися у кінці XVIII століття. До цього часу юриспруденція мала прикладний характер, відсутність напрацювань у теоретичних й практичних питаннях кримінального права, унеможливила складення будь-якої повноцінної картини без суб’єктивно-творчих доповнень.

М.С. Таганцев підкреслював: «вісімнадцяте століття не було придатним для догматичних робіт: переробка всього суспільного і державного ладу, що розпочалася, висунуті на перший план вчення про права особистості і гарантії свободи у державі не могли змиритися із законодавством, що корінилося у принципах інквізиційного процесу, в епосі забобон і релігійної нетерпимості» [9, с. 32].

Правова платформа змістилася на шлях гуманізації після трактату італійського мислителя Ч. Беккаріа «Про злочини і покарання». Широкі дискусії щодо доцільності смертної кари у доктрину царської Росії прийшли пізніше, хоча, ще у 1770 р. С.Ю. Десницький розглядав у «Слові про причини смертних кар у справах кримінальних" питання застосування смертної кари. Учений не заперечував її прийнятність, однак, лише у двох випадках - умисне вбивство і зрада Батьківщині, й категорично виступав проти негуманних способів її виконання. Спеціально досліджували проблему О.Ф. Кістяковський та М.Д. Сергеєвський. 
Професор Київського університету О.Ф. Кістяковський у роботі «Дослідження про смертну кару» виділив п'ять основних недоліків смертної кари: 1) людське життя - благо непорушне і невідчужуване; 2) смертна кара не лякає і не стримує людей, схильних до вчинення тяжких злочинів; 3) смертна кара приносить шкоду; 4) помилка при застосуванні смертної кари непоправна; 5) смертна кара позбавляє злочинця можливості виправитися.

Відкидали ідею смертної кари у монографічних дослідженнях А.А. Піонтковський - «Смертна кара в Європі» (1908) й М.М. Гернет - «Смертна кара» (1913).

Науковцями царської доби розпочалося вивчення окремих видів покарань. Так, у 1848 своїми історико-юридичними роздумами у роботі «Про покарання, що існували у Росії до царя Олексія Михайловича» поділився дослідник проблем правової науки Ф.Ф. Депп. Важливим дослідженням у розвитку категорії «позбавлення свободи» стала праця С.М. Будзинського. Він виокремлював «тюремне ув'язнення, вигнання з держави, інтернацію, делегацію й поліцейський нагляд» [3, с. 260].

Тілесні покарання були об’єктом вивчення В.Д. Спасовича у «Підручнику кримінального права», О.М. Богдановського у докторській дисертації «Молоді злочинці. Питання кримінального права і кримінальної політики», М.Д. Сергеєвського у «Покаранні в російському праві XVII ст.», а у 1897 р. друком вийшла робота приват-доцента Імператорського С.-Петербурзького університету О.Г. Тимофєєва «Історія тілесних покарань у російському праві» .

У дослідженнях вчених дореволюційного періоду дефініція «система покарань» не визначалася, хоча, сам термін вживався. Так, професор М.О. Максимович пише: «...у житті слов'яно-російського народу... покарання проявлялося у трьох різних видах, або системах. Давню систему покарань у Росії складала приватна помста за злочин і нанесену образу, і плата винагороди, чи викуп за відмову від помсти; наступну систему покарань складала смертна кара і тілесні покарання; вона може бути названа системою залякування чи публічної помсти; нарешті, третю систему складають покарання юридичні у вузькому значенні цього слова, що виражають прагнення зробити злочинця нешкідливим, морально покращеним і для держави корисним» [5, с. 10].

Ідеї, що докорінно відрізнялися від досліджень, вступне слово яких розпочиналося подякою «за спокій...під скіпетром Мудрого Помазанника Божого Благочестивого Государя Імператора» [5, с. 1], вказували на огріхи самодержавно-кріпосного ладу й недоліки антагоністичного суспільства містилися у роботах революціонерів-демократів. Формування прогресивно-критичних поглядів відбулося у роботі O.І. Герцена «Былое и думы».

Із дореволюційної доктрини пішла традиція виокремлювати декілька підходів до розгляду категорії «система і види покарань». Перший розглядає систему покарань як перелік усіх покарань, що розташовані у певному порядку, таких поглядів у часи царизму дотримувалися О.М. Попов, Ф.Ф. Депп, О.М. Богдановський, П.Д. Колосовський послідовниками цього підходу стали Л.В. Багрій-Шахматов, Т.О. Лєснієвські-Костарєва, В.В. Сташис, М.І. Бажанов, П.Л. Фріс та інші.

Другий полягає у розгляді видів покарань як таких, що утворюють особливу систему (сукупність), у рамках якої виявлялися внутрішні взаємозв'язки між 
окремими видами. Підтримку такий підхід знайшов у роботах дореволюційних науковців В.Д. Спасовича й А.А. Жижиленко. Знайшов подальше відображення у працях Л.Л. Кругликова, О.В. Старкова, С.Ф. Мілюкова та інших.

Необхідність вивчення доктрини кримінального права царизму не викликає сумнівів. Вона обумовлюється, перш за все, значенням ідейної спадщини попередників марксизму: 1) у найбільш загальних тенденціях система покарань дореволюційними вченими супроводжувалася впливом класичної і соціологічної шкіл; 2) закладено початки дискусії про змістовні і функціональні особливості категорії «система покарань», що триває й сьогодні; 3) у кримінальні доктрині знайшла відображення ідеологія, характерна для часів царизму; 4) подальший радянський рух у сторону юридичної реформи й переосмислення цілей покарання була неможливою без детального аналізу теорій, вироблених дореволюційними ученими.

Жовтнева революція 1917 р. знищила обох - старий царський політичний режим i, що важливо, традиційний порядок. Царський закон був непотрібним для більшовиків. Злом кайданів минулого повинен був відбутися шляхом нової правової основи і нової доктрини.

Взявши на озброєння ідеї соціологічної школи - «школи компромісу», за словами М.О. Чельцова-Бебутова [12, с. 55], особливості якої полягали у тому що: 1) репресія - тимчасова, у комуністичному суспільстві їй немає місця; 2) класовості кримінально-правових норм - спочатку характер небезпечності злочинця, а потім - характер небезпечності вчиненого злочину; доповнивши їх простою формулою: інтереси суспільства=інтереси пролетаріату і марксистською філософією з тезою про цілющу силу праці як один з основних факторів реінтеграції соціально небезпечної людини в суспільство, радянська влада почала будувати й нову систему покарань.

Традиція при призначенні покарання враховувати ступінь і характер соціальної небезпеки злочинця, його соціальну приналежність судом пішла ще із Керівних засад кримінального права РСФСР 1919 р. У червні 1922 р. у силу вступив КК УРСР. У 1922 р. законодавець визнавав покарання мірою оборони, воно повинно було бути доцільним і не містити ознак мук, а також не повинно було доставляти злочинцю безкорисних і зайвих страждань (ст. 26 КК). Здавалося би, можна говорити про гуманізацію системи, однак, підхід, що обрав радянський законодавець до побудови системи покарань (від найсуворішого до найм'якішого) це гуманістичне спрямування спотворює, а положення ст. 24 КК: «при визначенні міри покарання враховується ступінь й характер небезпеки, як самого злочинця, так і вчиненого ним злочину...» відкидало ще й ідею соціальної справедливості.

Щодо принципу законності, який Л.В. Багрій-Шахматов описав як такий, що «передбачав побудову системи покарань у точній і неухильній відповідності з положеннями і духом основних законів Радянської держави...» [1, с. 42], то він, умістившись у положення Конституції 1918 року про «встановлення диктатури міського і сільського пролетаріату і бідного селянства... 3 метою повного придушення буржуазії...», очевидно, проявлявся у законності, як організації правового режиму в розумінні революціонерів, а не законності як методу забезпечення однаковості сили закону для будь-яких осіб. 
Кримінальний кодекс відмовився від невизначених покарань, але допускав аналогію.

Розділ IV «Роди і види покарань й інших заходів соціального захисту» містив ст.32 яка відображала систему покарань. Було передбачено наступні види: 1) вигнання за межі УРСР на строк чи безстроково; 2) позбавлення волі із суворою ізоляцією чи без неї; 3) примусові роботи без утримання під вартою; 4) умовне засудження; 5) конфіскація майна; 6) штраф; 7) громадська догана; 8) покладення обов'язку загладити спричинену шкоду.

Максимальний строк позбавлення волі - 10 років. Види злочинів, які, на думку, ідеологічних юристів були найбільш небезпечними - контрреволюційні. Через КК простежувалася тенденція переваги інтересів держави над особистістю: для прикладу умисне вбивство передбачало санкцію не менше 8 років позбавлення волі із суворою ізоляцією, провокація підкупу могла загрожувати позбавленням волі із суворою ізоляцією або вищою мірою покарання (ст.115), організація у контрреволюційних цілях озброєних повстань... - вищою мірою із конфіскацією всього майна (ст.58).

Додатковими покараннями визнавалися грошове (штраф), майнове стягнення (конфіскація), ураження прав. Так, «ухилення від навчальних зборів...» (ст.81 б) каралася примусовими роботами строком до 3-х місяців із обов'язковим штрафом до 300 рублів золотом, а «підробка грошових знаків... за попередньою змовою декількох осіб...» (ст.85) - вищою мірою покарання (із пониженням у разі пом'якшуючих обставин до позбавлення волі строком не нижче 3-х років із суворою ізоляцією) 3 конфіскацією майна. Ураження прав полягало у позбавленні строком не більше 5-ти років активного і пасивного виборчого права, активного і пасивного виборчого права в професійні й інші організації; права займати відповідальні посади й бути засідателем у Народному суді, захисником у суді, поручителем й опікуном, цивільних й майнових прав, передбачених Цивільним кодексом. Для прикладу, «присвоєння чи розтрата посадовою особою грошей, цінностей...» (ст.113) каралася позбавленням волі строком до 1-го року й звільненням з посади. Дозволялося накладати декілька додаткових покарань: «ухилення від явки на мобілізацію... вчинене особами командного, адміністративного, комісарського складу...» (ч.2 ст.81д) каралося конфіскацією частини майна, поєднаною із забороною займати командні, адміністративні, комісарські посади із позбавленням волі строком не менш як три роки.

Смертна кара до переліку не входила, а визнавалася заходом тимчасовим і винятковим. Застосовувалася смертна кара у вигляді розстрілу виключно у справах, які знаходилися у провадженнях Верховного суду, Губернських судів і революційних трибуналів. Не застосовувалася до осіб, що не досягли віку 18 років і вагітних жінок - цей припис зберігся в усьому кримінальному кодифікованому законодавстві й далі. Якщо з моменту вчинення злочину пройшло не менше 5 років розстріл підлягав заміні на розсуд суду.

Висвітлення теми системи покарань у радянський період було завідомо одностороннім, апріорі відкидаючи, наприклад, які-небудь позитивні сторони кримінальної політики епохи імперії, хоча дещо навіть запозичено. Так, Кодексом 1922 р. (ст.49) було використано один з методів царської юстиції - превентивне адміністративне вислання (строком до 3 -х років). 
Розвиток кримінального права визначався перш за усе партійними установками й ідеологічним підходом. Політична складова кримінального покарання простежувалася у тому, що заходи кримінальної репресії використовувалася радянською владою, перш за усе, для придушення "класових ворогів», а уже потім для вирішення завдань, які зазвичай ставляться перед цим інститутом. За знищення «антирадянських елементів» ратувала й доктрина. Л.М. Саврасов, відкидаючи принцип виправлення у відношенні класових ворогів писав: «Від них ми повинні позбуватися... А тому, застосовуючи у цілому численні положення, вироблені буржуазною пенітенціарною наукою і застосовуючи їх до певних категорій злочинців... ми вводимо принцип, нехай старий, навіть архаїчний принцип кари, помсти» [6, с. 195].

У 1927 році було прийнято новий КК УРСР, який було прийнято на підставі Основних засад кримінального законодавства СРСР і союзних республік 1924. Соціологічне вчення вилилося у цілу теорію соціального захисту. Наполягаючи на відмові від покарання як помсти, термін «покарання» було замінено «заходами соціального захисту» .

Немировський Е.Я. писав: «Уже при обговоренні проєкту Кодексу 1922 р. роздавалися голоси проти збереження терміну покарання, яке відповідає побудові кримінальної відповідальності на основі індивідуальної вини, тоді як радянське законодавство відмовилося від цієї точки зору і в основу репресії кладе небезпечність злочинця; таким чином, репресія не містить у собі елементу помсти, а є заходом захисту суспільства» [7, с. 7].

М.Д. Шаргородський виключення із радянського законодавства терміна «покарання» визнавав помилковим, наголошуючи, що «відмова від терміна покарання у законі не відображала яких-небудь принципових змін у поглядах на завдання кримінального права, а лише свідчила про бажання законодавця підкреслити відмову від покарання як від помсти, хоча для цього не потрібно було змінювати стару термінологію» [16]. Підтримував цю позицію і радянський правник О.Я. Естрін. Попри сувору критику, ідея помсти не пішла у забуття. Б.С. Утевський був першим серед радянських вчених, хто розглядав помсту як ціль кримінального покарання [11, с. 222]. Цю точку зору підтримував А.М. Яковлев, А.Н. Тарбогаєв, Л.І. Спиридонов та інші.

Кодекс 1927 у розділі 4 «Заходи соціального захисту, застосовувані за цим кодексом» зберіг диференціацію видів покарання: 1) оголошення ворогом трудящих з позбавленням громадянства УРСР і тим самим громадянства Союзу РСР і вигнання межі Союзу РСР назавжди; 2) позбавлення волі у виправно-трудових таборах у далеких місцевостях Союзу РСР; 3) позбавлення волі в загальних місцях ув'язнення; 4) виправно-трудові роботи без позбавлення волі; 5) обмеження прав; 6) видалення за межі Союзу РСР на строк; 7) видалення за межі УРСР чи окремої місцевості з оселенням у тих чи інших місцевостях або без такого оселення, із забороною проживати в тих, чи інших місцевостях або без такої заборони; 8) звільнення з посади із забороною займати певну посаду або без такої заборони; 9) заборона займатися конкретним видом діяльності чи промислу; 10) громадська догана; 11) конфіскація майна; 12) штраф. 
Як і у попередньому КК розстріл не входив до системи покарань, а застосовувався як винятковий захід соціального захисту і згідно Указу Президії ВР СРСР від 26.05.1947 не застосовувався у мирний час, його мало бути замінено ув'язненням у виправно-трудовий табір строком на 25 років. Шпигунство, шкідництво та інші диверсійні акти почали мати альтернативну санкцію: розстріл або ув'язнення до 25 років.

Статтями КК було більш конкретизовано перелік самостійних і додаткових видів покарань: вигнання, позбавлення волі і виправно-трудові роботи, згідно ст. 22 були самостійними. Всі інші заходи, могли бути як самостійними, так і додатковими. Так, тепер конфіскація і штраф не була суто додатковим заходом, наприклад, ст.60 передбачала конфіскацію всього або частини майна «за утаювання спадкового майна, або майна, що переходить за актами дарування...», а ст. 68-1 - штраф до трьохсот карбованців «за подання завідомо неправдивих відомостей органам реєстрації актів громадянського стану або судовим органам...» .

Цим кодексом здійснено пом'якшення окремих видів покарання, розширення покарань, не пов'язаних із позбавленням волі.

Вчення радянської держави про кримінальне покарання пов'язується із його виховною функцією. Тут можна говорити й про те, що радянська держава у сфері кримінального права певною мірою застосовувала принцип гуманізму, про який у 1963 написав Л.В. Багрій-Шахматов, однак, норми права, що відображали принцип гуманізму, далеко не завжди утілювалися у практичній діяльності. І ця різниця між «паперовими» і дійсними умовами збільшувалася рік за роком досягнувши

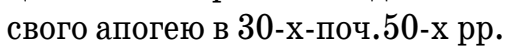

У жовтні 1960 було прийнято КК УРСР, лише у ньому кримінальне законодавство звільнилося від класового підходу при призначенні покарання. Принцип рівності ще не сформульовано, однак можна говорити про індивідуалізацію покарання у повному сенсі цього слова, адже, ст. 32 КК було передбачено, що суд враховує характер і ступінь суспільної небезпеки вчиненого злочину, особистість винного і обставини справи, що пом'якшують або обтяжують відповідальність. Відкинуто принцип застосування законодавства за аналогією. Ст.23 визначала наступні види покарання: 1) позбавлення волі на певний строк; 2) заслання; 3) вислання; 4) виправні роботи без позбавлення волі; 5) позбавлення права займати певні посади чи займатися певною діяльністю; 6) штраф; 7) громадська догана. До військовослужбовців могло застосовуватися покарання у вигляді направлення до дисциплінарного батальйону. Усі покарання, крім позбавлення права займати певні посади або займатися певною діяльністю штрафу, заслання і вислання були основними, перелічені могли бути як основними, так і додатковими. Застосовувалися такі додаткові покарання: 1) конфіскація майна; 2) позбавлення військового, спеціального звання, рангу, чину, кваліфікаційного класу; 3) позбавлення батьківських прав. Заслання, вислання, конфіскація майна і штраф могли застосовуватися лише тоді, коли вони були прямо передбачені статями Особливої частини КК. Традиційно за межами переліку системи покарань стояла смертна кара у вигляді розстрілу, їй було присвячено ст. 24 КК УРСР.

Фундаментальна робота у радянські часи належить Л.В. Багрію-Шахматову. Так, у роботі «Система покарань за радянським кримінальним правом, її класифі- 
кація і правове регулювання виконання», надається не лише аналіз системі покарань в історичній ретроспективі, але й її принципів, які автор розділяє на загальні (класовості, законності, гуманізму, демократизму) й спеціальні (невідворотності, індивідуалізації, визначеності доцільної репресивності, економії каральних засобів). Подальшого розвитку ідеї набули у роботі Л.В. Багрія-Шахматова і В.І. Гуськова «Теоретичні проблеми класифікації кримінальних покарань» (1971).

До розробки й вивчення системи покарань у радянському праві долучилися P.P. Галіакбаров, О.С. Горелік, I.I. Карпець, І.С. Ной, О.В. Наумов, М.I. Васильєв та інші.

Розробкою теорії й вивченням історії окремих видів покарань займалися: Б.С. Утевський, Шервиндт Є.Г. «Радянське пенітенціарне право», (1927), В.I. Тютюгін «Позбавлення права займати певні посади як вид покарання за радянським кримінальним правом» (1982), Гаджиєв X.I. «Штраф як вид покарання за радянським кримінальним правом» (1987), Ізмаїлов I.А. «Штраф як міра кримінального покарання»(1972), Дементьєв С.І. «Побудова кримінально-правових санкцій у вигляді позбавлення волі» (1986), В.О. Рогов «В’язниці й позбавлення свободи у середньовічній Росії (кінець XV-поч.XVII ст.)» (1987), Сафронов Ф.Г. «Заслання у Східну Сибір у XVII ст.» (1967) тощо.

B.I. Тютюгін і M.I. Бажанов приділяли увагу особливостям застосування додаткових покарань. Так, M.I. Бажанов зазначав: «додаткові покарання є важливим засобом ефективності приватного і загального попередження, вони забезпечують втілення принципу індивідуалізації покарання у радянському праві» [2, с. 126].

Радянська доктрина покарання: 1) була заснована на марксистсько-ленініській концепції детермінізму («наука проти обскурантизму»); 2) існуючі в теорії радянської науки підходи до розвитку системи покарань не повністю відображали еволюцію концептуальних ідей покарання. Встановлення загальних тенденцій розвитку передбачає не лише вивчення його ґенези, але й закономірностей спадкоємності різних епох, яка відкидалася; 3) теорія системи покарання у розумінні радянських вчених втрачала зв'язок із загальними принципами класичної школи кримінального права і все більше тяжіла до соціологічної, де винність як один з основних принципів до уваги не брався.

Вивчення особливостей системи покарань стало напрямом наукових досліджень у незалежній Україні, відправною точкою яких стало прийняття у 2001 р. Кримінального кодексу України.

Системою покарань вітчизняні науковці називають встановлений ст. 51 КК України обов'язковий для суду вичерпний перелік покарань, розташованих у певному порядку з урахуванням їх порівняльної суворості, що утворюють у сукупності єдине ціле. Таке розуміння системи покарань із деякими уточненнями термінології у різних вчених (Грищук В.К., Фесенко Є.В., Фріс П.Л., Бажанов М.І. тощо) $\epsilon$ визнаним у теорії сучасного кримінального права. В.І. Тютюгін наголошує: «законодавчий перелік видів покарань, що закріплює у ст.51 КК систему покарань, побудований на основі єдиного критерію (принципу) - за ступенем сировості покарання... така законодавча побудова переліку покарань дозволяє і відповідним чином конструювати санкції статей Особливої частини КК, і вирішувати питання про суворість покарання при його призначенні...» [10]. 
В.В. Сташис, вважаючи систему покарань «тією юридичною базою, на якій грунтується діяльність суду із застосування покарань», виділяв наступні ознаки української системи покарань: 1) обширність (складається із 12 видів покарань); 2) закритість (перелік є обов'язковим для суду і він не може вийти за межі законодавчого переліку); 3) побудована за принципом від менш суворого до більш суворого; 4) покарання можуть бути класифіковані за різними підставами [8].

Система покарань протягом тривалого часу була предметом вивчення ряду фахівців - В.Я. Тація, О.А. Козакова, Н.Ф. Кузнєцової, І.І. Митрофанова, О.В. Старкова, В.В. Сташиса, П.Л. Фріса, Д.А. Шевченко, С.П. Старосольської та ін. Аспекти покращення системи покарань у відношенні до неповнолітніх висвітлювали у своїх роботах Н.А. Мірошниченко, Н.Л. Березовська, В.М. Бурдін та інші.

Існує й ряд проблем в українській системі покарань. Так, зміни, внесені до КК Законом України «Про внесення змін до деяких законодавчих актів України щодо гуманізації відповідальності за правопорушення у сфері господарської діяльності» № 4025-VI від 15.11.2011 посягнули на їі логічну завершеність, оскільки місце штрафу в системі перестало відповідати його м'якості. Серед глобального нова кримінально-правова реформа, суттєві аспекти якої містяться у Законі України «Про внесення змін до деяких законодавчих актів України щодо спрощення досудового розслідування окремих категорій кримінальних правопорушень», набрання чинності якого відкладено на 1 липня 2020 року.

Висновки. Система покарань у різні історичні періоди ставала предметом аналізу правників й істориків. Перелік, що утворював систему покарань починаючи із перших нормативно-правових актів, залежав від соціально-економічної формації і повністю відображав кримінально-правову політику держави. Досягнення науки кримінального права періоду царизму проявилося у зародженні вчення про систему покарань. У Радянській період автори його розвивали відповідно до утверджених соціалістичних принципів, із позиції класового підходу.

Загальносвітова тенденція гуманізації знайшла своє утілення у побудові системи покарань незалежної України, а гнучкість кримінально-правової науки проявилася у можливості проведення досліджень вільних від ідеології.

Практична законотворча діяльність переганяла теоретичні дослідження (що історично не могло бути інакше) й подальший розвиток доктрини в Україні на тлі змін, оновлення дефініційно-категоріального апарату може створити нову теоретичну модель системи покарань шляхом осмислення накопиченого досвіду.

\section{Jimepamypa}

1. Багрий-Шахматов Л.В. Система уголовных наказаний и их классификация / Багрий-Шахматов Л.В. Минск, 1972.110 с.

2. Бажанов М.И. Избранные труды / М.И. Бажанов; [сост.: В.И. Тютюгин, А.А. Байда, Е.В. Харитонова, Е.В. Шевченко; отв.ред. В.Я. Таций]. Харьков : Право, 2012. 1244 с.: ил.

3. Будзинский С.М. Начала уголовного права. Соч. С. Будзинского. Варшава, 1870. 376 с.

4. Галицько-Волинський літопис. Відпов. за вип., вступна стаття Р.М. Федорів, худ. оформ. М.I. Яців. Львів : «Червона калина», 1994. 258 с.

5. Максимовичь М.А. Речь объ уголовныхъ наказаніяхъ въ России. Кіевъ, 1853. 261 с.

6. Наумов А.В. Российское уголовное право : курс лекций: в 3 т. Т. 1: Общая часть, 736 с. 
7. Немировский Э.Я. Новейшие изменения советского уголовного законодательства / проф. Э.Я. Немировский // изд. Одессого института народного хазяйства, 1927. 292 с.

8. Сташис В.В. Актуальные вопросы системы наказаний по Уголовному кодексу Украины 2001 года / Ежегодник украинского права. [Електронний ресурс]: Режим доступу: http://dspace.nlu. edu.ua/bitstream/123456789/420/1/Stashis2011\% 20223.pdf. - Назва з екрану.

9. Таганцев Н.С. Русское уголовное право: (Часть Общая). Т.1. / Тула : Автограф, 2001, 800 с.

10. Тютюгин В.И. Вопросы наказания и его назначения в трудах профессора М.И. Бажанова / В.И. Тютюгин / Ученики о научном наследии профессора М.И. Бажанова (по материалам «круглого стола», посвященного 90-летию со дня рождения М.И. Бажанова). Харьков : Право, 2013. С. 31-39.

11. Уголовное право: Общая часть / Под общ. ред. И.Т. Голякова. 3-е изд., перераб. и доп. М. : Госюриздат, $1943.284 \mathrm{c}$.

12. Чельцов-Бебутов М.А. Социолистическое правосознание и уголовное право революции. Харьков : Юрид. изд-во НКЮ УРСР, 1924, 92 с.

13. Чугаєва I.К. Чернігівське літописання XI-XIII ст.: історіографічний міф чи історичне джерело? [Текст] : монографія: І.К. Чугаєва: відп. ред. В.О. Дятлов. Чернігів. ПАТ «ПВК» «Десна», 2018. 336 с.

14. Шаргородский М.Д. Наказание по советскому уголовному праву. М. : Госюридиздат, 1958, 240 c.

\section{Анотація}

Басалюк Н. В. Система покарань у доктрині кримінального права України. - Стаття.

У статті приділяється увага тенденціям розвитку вчення про систему покарань у вітчизняній кримінально-правовій доктрині з їі розподілом на конкретні етапи. На основі проведеного аналізу зроблено висновок відносно існуючої в українському законодавстві системи покарань і прогноз щодо можливих перспектив її подальшого розвитку.

Важкко уявити сучасні дослідження без звернення до характеру та змісту порівняльно-історичних розробок вчених минулого. Зародження доктрини про систему покарань розпочалося у дореволюційні часи із характеристики видів покарань, які отримали необхідне обгрунтування в теорії кримінального права часів царизму.

Подальша теоретична розробка припадає на радянський період. Радянське кримінальне законодавство було побудоване на принципі верховенства інтересів держави над інтересами особистості, який втілився у ключові юридичні категорії. У цей час відбулося становлення системи покарань, що відповідала соціалістичним принципам й революційним соціально-економічним цінностям. Ідентичним шляхом відбувався розвиток й доктрини кримінального права, яка висловлювала підтримку класовому підходу, що виражався у підкоренні винуватості політичним інтересам, тяжіла до ідеологічного фактору формування вихідної концепції системи покарань й вчення соціологічної школи, на відміну від дореволюційного кримінального законодавства, що йшло шляхом класичної школи кримінального права.

Початок процесу становлення теорії кримінального права незалежної України розпочався із прийняття нового Кримінального кодексу у 2001 р. Побудова системи покарань відбувалася через призму принципів гуманізму, законності, рівності, індивідуалізації покарання. Сучасний стан вивчення системи покарань характеризується як з'ясуванням внутрішніх, органічних зв'язків її складових, так і їі розумінням як певної послідовності, переліку. Окремі види розглядаються не лише з позиції структурного аналізу, але й тлумачення. Однак, вироблення вчення про систему покарань як «ціле, зрозуміле, пов'язане» у зв'язку з реформуванням кримінального права ще попереду.

Ключові слова: кримінально-правова доктрина системи покарань, царська доба, радянський період, КК УРСР, діюче кримінальне законодавство України.

\section{Summary}

Basaliuk N.V. Punishment system in the doctrine of criminal law of Ukraine. - Article.

The attention in this article is being given to trends of development of studies about the domestic penalties system doctrine and its differentiation to specific stages. On the basis of the conducted analysis the conclusion concerning the system of punishments existing in the Ukrainian legislation and the forecast concerning possible prospects of its further development is made.

It is difficult to imagine modern research without reference to the nature and content of comparative and historical developments of scientists of the past.The emergence of penalties system doctrine has started at pre-revolutionary times from characterization of penalties forms, which have been provided with necessary just justification criminal law theory of tsarist period. 
Further theoretical development dates back to the Soviet period. Soviet criminal law system has been based on the principle of primacy of the State's interest over the person's interest, which has been implemented into main legal concepts. The formation of penalties system consistent with socialistic principles and revolutionary socioeconomic virtues happened in those times. In the same way was happening the development of criminal law doctrine embodying support to the class-based ideological approach with supervision of political interests and lean toward the socialistic views and ideological quotient of penalties system concept forming. In contrast to the pre-revolutionary criminal law, which followed the path of the classical school of criminal law.

Establishment process of criminal law theory in independent Ukraine started from enactment of renewed Criminal Code in 2001. Building of penalties system was holding through the prism of humanity, legality, equality and individualization of punishment principles. Modern phase of penalties system exploration is characterized by learning of internal connections of its component parts and their consistency. Specific types of penalties are being examined by both structural analyzing and interpretation. However, as result of Criminal Law reforming, elaboration of penalties system which may be considered as «complete, reasonable and bound» is still to come.

Key words: criminal-legal doctrine of punishment system, tsarist era, Soviet period, Criminal Code of the Ukrainian SSR, current criminal legislation of Ukraine. 